\title{
IMPLEMENTACIJA APLIKACIJE DUOLINGO U NASTAVU NJEMAČKOG KAO STRANOG JEZIKA
}

\author{
Nikolina Miletić* \\ Sveučilište u Zadru
}

\begin{abstract}
Aplikacija Duolingo ${ }^{1}$ popularna je $\mathrm{u}$ učenju stranih jezika diljem svijeta. $U$ analizi koja se prikazuje u ovom članku ispituje se mogućnost implementacije aplikacije Duolingo u nastavu njemačkog kao stranog jezika. Aplikacija se analizira s obzirom na odabir tema i uvježbavanje vokabulara koji se potom uspoređuju s onima u hrvatskim udžbenicima za nastavu njemačkog kao stranog jezika. Kako se hrvatski udžbenici za nastavu njemačkog kao stranog jezika pripremaju prema smjernicama Zajedničkog europskog referentnog okvira za jezike (ZEROJ) (2005), rezultati provedene analize pokazat će odgovara li aplikacija Duolingo smjernicama koje se za odabir tema mogu izvesti iz ZEROJ-a. Nadalje, rezultati analize pružit će odgovor na sljedeća pitanja: Postoje li sličnosti ili razlike $u$ a) odabiru tema, b) semantizaciji vokabulara te c) uvježbavanju vokabulara u aplikaciji i u udžbenicima? Svrha je analize utvrditi primjenjivost aplikacije Duolingo za učenje njemačkog kao stranog jezika kako bi se dao kontekstualni okvir istraživanju primjene navedene aplikacije.
\end{abstract}

Ključne riječi: mediji u nastavi stranog jezika, aplikacija Duolingo, poučavanje njemačkog kao stranog jezika.

\section{NOVI MEDIJI U UČENJU STRANOG JEZIKA}

Danas je nastava stranog jezika nezamisliva bez novijih elektroničkih medija. Osim osnovnog medija ploče, nastavnicima i učenicima stoje na raspolaganju i bijela ploča, flipchart ploča, magneti, CD i DVD, grafoskop, računalo, projektor i pametna ploča. Uz to je internet neiscrpan resurs materijala za učenje i poučavanje. Internet nastavnicima i učenicima omogućuje različite oblike komunikacije, kao što su e-pošta, društvene mreže (Facebook, Twitter itd.), WebQuests, (online) alati, platforme za učenje i aplikacije (usp. Brinitzer i sur., 2016).

Prema Brinkmannu (2000) razlikujemo pet dimenzija novih oblika i tehnika učenja. To su sugestivna, osjetilna, kreativna, zabavna i tehničkomedijska dimenzija. U praksi nastaje kombinacija tih dimenzija iz kojih proizlaze različite metode. Cilj je tehničko-medijske dimenzije nabava i obrada informacija. Ona omogućuje nastavnicima i učenicima ophođenje

\footnotetext{
$\overline{\text { *nmiletic2@unizd.hr }}$

${ }^{1}$ https://www.duolingo.com
} 
s velikim količinama informacija i samostalno učenje novim medijima (Brinkmann, 2000: 53).

Mediji ne utječu samo na naše razmišljanje i djelovanje, već i na način na koji komuniciramo. Svaki medijski preokret nosi sa sobom velike promjene i za nas (usp. Steinig i Huneke, 2011: 36).

Danas se izraz e-učenje koristi za razne oblike učenja mrežnim medijima. Mogućnosti su e-učenja različite i ovise o ciljevima, metodama i/ili zahtjevima nastavnika i učenika (usp. Schmale i sur., 2007: 35). Novi mediji imaju različite funkcije, kao što su zabavljati, informirati ili mogu poslužiti kao bijeg od svakodnevnice (Grewe, 2011: 12). Velika ponuda novih medija dovodi do pitanja koji su od njih prikladni za djecu i adolescente. U tu svrhu Institut für Publizistikwissenschaft und Medienforschung der Universität Zürich (Institut komunikologije i primijenjenih medijskih istraživanja Sveučilišta u Zürichu) provodi istraživanja i daje nastavnicima i roditeljima informacije o uporabi i kvaliteti tih medija (usp. Süss, 2004: 64). Primjerice, u studiji Studieren im Web 2.0 o kojoj izvješćuju Kleimann, Özkilic i Göcks (2008) empirijski je istraženo kojim se internetskim sadržajima studenti najčešće koriste. Rezultati istraživanja pokazuju da se studenti najčešće koriste internetskom enciklopedijom Wikipedijom. Na drugom su mjestu društvene mreže (Facebook, StudiVZ, MySpace, Xing itd.), na trećem chatovi i izravne poruke, na četvrtom video zajednice (npr. YouTube), na petom Wikis i zatim slijede online igrice i blogovi.

Danas se uz pojam e-učenja često koristi i pojam m-učenje ili MALL (Mobile-Assisted Language Learning). To je oblik učenja čiji je cilj povezivanje nastave jezika s učenikovim svakodnevnim korištenjem medija (Feick, 2015: 14). Mogućnosti koje nudi m-učenje povezuje učenje u učionici i izvan učionice, odnosno učionice postaju dio stvarnog vanjskog svijeta (Feick, 2015: 15). Aplikacija Duolingo jedna je od mogućnosti m-učenja koja će u nastavku biti detaljnije predstavljena.

\section{APLIKACIJA DUOLINGO}

Duolingo je besplatna aplikacija za učenje jezika. Trenutačno se njome za učenje stranih jezika koristi 200 milijuna ljudi. Ona omogućuje učenje 23 različita jezika, a među njima nije hrvatski, što znači da polaznici čiji je materinski jezik hrvatski trebaju odabrati neki drugi polazni jezik da bi učili njemački. Prednost je aplikacije što možete učiti bilo kada i bilo gdje. Odnedavno je moguće koristiti se aplikacijom i kao platformom za učenje jezika u učionici, odnosno nastavnici se mogu njome koristiti kao dodatnim nastavnim materijalom. Lekcije sadrže različite vježbe slušanja, govorenja, prevođenja i višestrukog izbora. Vrednovanje lekcija događa se neposredno, stoga učenici mogu odmah vidjeti svoje pogreške i pratiti svoj napredak (usp. Duolingo - https://www.duolingo.com). 
Vesselinov i Grego (2012) istraživali su učinkovitost Duolingo aplikacije kod korisnika aplikacije koji su učili španjolski jezik. Sudionici u istraživanju bili su izvorni govornici engleskog jezika u dobi od najmanje 18 godina, a izabrani su za sudjelovanje $u$ istraživanju metodom slučajnog odabira. $\mathrm{Na}$ početku istraživanja pisali su razredbeni ispit (engl. placement test). Nakon određenog razdoblja (okvirno osam tjedana) učenja jezika uz pomoć aplikacije pisali su još jedan ispit s ciljem utvrđivanja jezičnog napretka. Rezultati su pokazali da je došlo do statistički značajnog poboljšanja jezičnog znanja kod sudionika. Kao bitan faktor pokazala se razina početnog jezičnog znanja. Sudionici s vrlo niskim jezičnim znanjem ostvarili su veći napredak od sudionika s naprednijim jezičnim znanjem. Istraživanje je pokazalo da korisnici aplikaciju smatraju privlačnom i da im omogućuje velik napredak u učenju. Aplikacijom Duolingo korisnici mogu uvježbavati jezične strukture i vokabular. Kod učenja stranog jezika usvajanje i uvježbavanje vokabulara važni su faktori zbog čega slijedi poseban osvrt na njih u nastavku članka.

\section{ODABIR, SEMANTIZACIJA I UVJEŽBAVANJE VOKABULARA}

Vokabular se, baš kao i gramatika, u nastavi stranih jezika uči korak po korak, iako u didaktici ne postoji dosljedan i općeprihvaćeni način odabira i prezentacije vokabulara (Bohn, 1999: 43). U nacionalnom kurikulumu za Njemački jezik za svaku se razinu učenja predlažu teme koje autorima udžbenika mogu služiti kao smjernice u odabiru tema. Neki se načini prezentacije vokabulara u udžbenicima ponavljaju više puta, kao npr. čitanje ili slušanje tekstova, slike, popis vokabulara, pravila tvorbe riječi i pravila za rukovanje rječnicima (Bohn, 1999: 43). Semantizacija vokabulara uključuje verbalne i neverbalne metode. Neverbalne su metode piktogrami, prometni znakovi, brojevi, znakovi, figurativna ilustracija, slikovna ilustracija, geste, mimika, pantomima i zvučne slike. Verbalne metode semantizacije mogu biti jednojezične i/ili dvojezične. Jednojezični su načini semantizacije objašnjenja vokabulara kroz kontekst, paradigmatične odnose u značenjskim objašnjenjima (sinonimi, antonimi, tvorba riječi, nizovi), logičkokonceptualne odnose $u$ značenjskim objašnjenjima (hijerarhije, analogije, jednadžbe) i opisna značenja (definicije, primjeri, parafraze). Dvojezični su načini semantizacije prijevodi, sličnosti u materinskom i stranom jeziku, sličnosti u prvom i drugom stranom jeziku i internacionalizmi. Dvojezični načini semantizacije uključuju ograničenja koja se odnose na ispravnost i pouzdanost. Što se polazišna i ciljna kultura više razlikuju, to su veće razlike u značenju riječi (Bohn, 1999: 70).

Müller (1994) navodi konkretne postupke za interkulturnu interpretaciju značenja koji se mogu odraditi u dvije nastavne faze. U prvoj se fazi identificira predmet objašnjenja, odnosno učenici trebaju razumjeti koji se predmet objašnjava, a u drugoj se fazi predmet predstavlja u okviru 
određene kulture, odnosno učenici trebaju smjestiti riječ u kontekst koji je specifičan za tu kulturu. U nastavi je stranih jezika uobičajeno prvo objasniti značenje riječi, a nakon toga pronaći odgovarajući prijevod na materinskom jeziku. Takva su objašnjenja često kulturološki neutralna i apstraktna, jer se prikazuju izvan kulturnog konteksta.

Nakon što je vokabular prezentiran i semantiziran, učenici ga trebaju uvježbavati. Neuner, Krüger i Grewer (1981: 2f.) razradili su tipologiju vježbi za komunikativnu nastavu njemačkog jezika. Prema njihovoj tipologiji vježbe mogu biti receptivne, reproduktivne, reproduktivno-produktivne i produktivne naravi. Receptivnim se vježbama provjerava razumijevanje teksta, a učenici pri tome ne trebaju samostalno usmeno ili pismeno producirati, nego povezati, zaokružiti ili prekrižiti izjave. Reproduktivne vježbe vode učenika prema produkciji uz korištenje zadanim obrascima, najčešće je riječ o ponavljanju vokabulara ili jezičnih struktura te njihovoj kontekstualizaciji. Reproduktivno-produktivne vježbe nalaze se između vježbi reproduktivnog i produktivnog karaktera. Takve vježbe sadrže tekstne obrasce, natuknice, vokabular itd. koji učenicima omogućavaju prijelaz s reprodukcije na produkciju. Produktivnim vježbama učenici mogu pokazati cjelokupno znanje stranog jezika. Kod takvih vježbi učeniku ne stoje na raspolaganju natuknice kao dodatna pomoć pri produkciji. U nastavi je njemačkog jezika bitno držati se smislene strukture vježbi, tj. početi s jednostavnijim vježbama i postupno ići prema kompleksnijima.

\section{ANALIZA APLIKACIJE DUOLINGO}

\subsection{Cilj i metoda analize}

Cilj je analize utvrditi mogućnosti korištenja vokabulara s aplikacije Duolingo kao dopunskog nastavnog materijala u obradi vokabulara i pri učenikovu samostalnom učenju njemačkog jezika. U svrhu postizanja toga cilja analizira se odabir tema, semantizacija i uvježbavanje vokabulara u aplikaciji. Odabir tema, semantizacija i uvježbavanje vokabulara s aplikacije Duolingo uspoređuje se $\mathrm{s}$ onima $\mathrm{u}$ hrvatskim udžbenicima za njemački kao strani jezik, a kao korpus uzeta je udžbenička serija zweite.sprache@ DEUTSCH.de 1-4 za srednje škole (gimnazije i strukovne škole) autorica Horvatić Čajko i Lasić (2006, 2008, 2009, 2013) u izdanju najveće hrvatske izdavačke kuće Školska knjiga. Udžbenici su prema ZEROJ-u namijenjeni za osnovnu (A1/A2) i samostalnu (B1) jezičnu razinu.

\subsection{Rezultati analize}

U aplikaciji Duolingo korisniku stoji na raspolaganju 58 tematskih jedinica. Neke se teme ponavljaju nekoliko puta, kao npr. apstraktni objekti 1, apstraktni objekti 2, apstraktni objekti 3 i apstraktni objekti 4 . U nastavku 
će se prikazati odabir tema, način semantizacije i uvježbavanje vokabulara u aplikaciji Duolingo i usporediti s temama i vokabularom iz četiri hrvatska udžbenika za nastavu njemačkog jezika.

Analiza primjerenosti tema $\mathrm{s}$ aplikacije Duolingo prema jezičnim razinama (v. ZEROJ) prikazuje mogućnost uključivanja tema u nastavu njemačkog jezika. Teme hrana, životinje, odjeća, priroda, mjesta, kuća, obitelj, brojevi, boje, vrijeme, upute, dijelovi tijela, jezik i sport mogu se koristiti na razini A1. Teme svijet (vokabular Sjeverni pol, Južni pol, tradicije, kontinenti, države), emocije, novac, kupovina mogu se uvesti na razini A2. Teme klasična glazba, poslovi, zanimanja i putovanja mogu se implementirati na jezičnoj razini B1.

Usporedba tema zastupljenih $u$ aplikaciji Duolingo $s$ onima $u$ udžbenicima za njemački kao drugi strani jezik pokazuje da teme poput politika, religija, materijali, medicina, emocije, duhovnost, bankarstvo, apstraktni predmeti, filozofija, umjetnost, znanstvena fantastika itd. s aplikacije Duolingo nisu navedene $u$ udžbenicima za njemački jezik. Iako se teme s aplikacije Duolingo ne nalaze u udžbenicima, vokabular iz tih područja provlači se kroz druge slične teme iz udžbenika. Pod temom politika javlja se vokabular odluke, vlast, republika, kontrola, povijest, pravila, rat, mir, država, interes, sloboda, ekonomija, strategija, policija, zahtjevi, uredi, savezi, savjeti itd. Pod temom banke pojavljuje se vokabular kreditne kartice, kovanice, tekući račun, plaćanje, računi, novac itd. Vokabular na temu politika prisutan je u udžbenicima na razini B1, a vokabular na temu banka već na razini A2.

Udžbenici sadrže teme koje nisu navedene u aplikaciji Duolingo, kao što su praznici, škola, prijatelji, generacijski sukobi, simpatija, sezonski rad, savjeti za ljepotu, punoljetnost, kućanski poslovi, ovisnosti, prestanak pušenja, oglašavanje, medij itd. Teme i vokabular iz udžbenika za njemački jezik prilagođeni su dobi učenika, dok su teme s aplikacije neutralnije, tj. primjenjive i za mlade i za odrasle.

Analiza je pokazala da postoje teme koje se nalaze i $u$ aplikaciji i $u$ udžbenicima. To su teme koje se odnose na svakodnevnicu, poput tema hrana, odjeća, mjesta, zemlje, ljudi, novac, obitelj, dijelovi tijela, boje, vrijeme, vremenska prognoza itd.

U nastavku su tablično prikazane teme koje se pojavljuju u aplikaciji Duolingo i u hrvatskim udžbenicima za njemački jezik: 
Miletić: Implementacija Aplikacije duolingo u nastavu... (str. 255-267)

Tablica 1. Teme u aplikaciji Duolingo i u udžbenicima za njemački kao strani jezik

\begin{tabular}{|l|l|l|}
\hline $\begin{array}{l}\text { Teme u aplikaciji Duolingo i u } \\
\text { udžbenicima za njemački jezik }\end{array}$ & $\begin{array}{l}\text { Teme samo u } \\
\text { aplikaciji Duolingo }\end{array}$ & $\begin{array}{l}\text { Teme samo u udžbenicima za } \\
\text { njemački jezik }\end{array}$ \\
\hline hrana & politika & objašnjavanje puta \\
\hline životinje & matigija & praznici \\
\hline odjeća & medicinali & škola, rođendan \\
\hline priroda & osjećaji & blagdani \\
\hline mjesta & duhovnost & selidba, prostor \\
\hline zemlja i ljudi & banke & prijatelji, moj razred \\
\hline obitelj & matematika & kućanski poslovi \\
\hline novac & znanstvena fantastika & obiteljski odnosi, generacijski konflikt \\
\hline dijelovi tijela & fimpatija, plišane igračke \\
\hline putovanja & likovna umjetnost & slobodno vrijeme \\
\hline boje & sezonski poslovi, džeparac \\
\hline zanimanja & & ovisnosti, savjeti za ljepotu \\
\hline vrijeme & & mediji, oglašavanje \\
\hline smjer kretanja & & institucije, povijest EU \\
\hline internet & & punoljetnost, bonton \\
\hline vremenska prognoza & & zemlje njemačkog govornog područja \\
\hline sport & & \\
\hline klasična glazba & & \\
\hline
\end{tabular}

Nakon usporedbe odabira tema i vokabulara s Duolinga s onima iz udžbenika, analiziran je način semantizacije vokabulara. U nastavku slijedi osvrt na neverbalni $\mathrm{i}$ verbalni način semantizacije $\mathrm{u}$ aplikaciji te njihova usporedba s onima u udžbenicima.

Neverbalni način semantizacije $\mathrm{u}$ obliku prikazivanja slika rijetko je zastupljen $u$ odnosu na druge oblike semantizacije. U aplikaciji se prikazuje slika objekta ili predmeta i učenik mora pravilno imenovati taj predmet (slika 1).

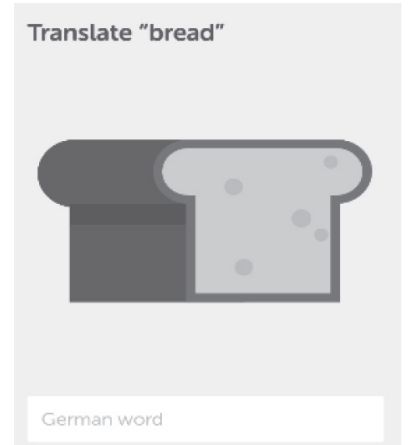

Slika 1. Neverbalni način semantizacije prikazivanjem slike 
U Duolingu se ne nalaze jednojezični načini semantizacije, već je najčešći dvojezični način semantizacije prevođenjem, primjerice prijevodi s engleskog na njemački ili s njemačkog na engleski. Pojavljuje se nekoliko varijanti prijevoda. Za neke su prijevode riječi već ponuđene i učenik ih mora samo poredati točnim redoslijedom. Uz to su ponuđene riječi koje su višak kako bi prevođenje bilo složenije (slika 2). Kod drugih prijevoda učenik mora samostalno unijeti cjeloviti prijevod (slika 3).

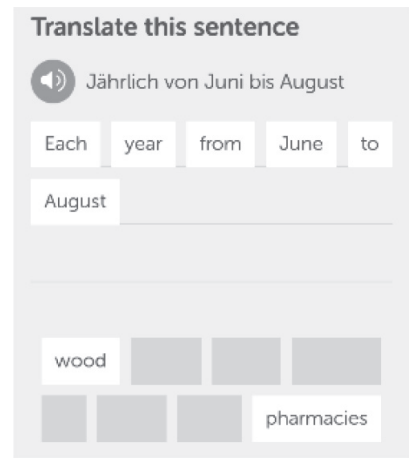

Slika 2. Dvojezični način semantizacije prevođenjem (s viškom ponuđenih riječi)

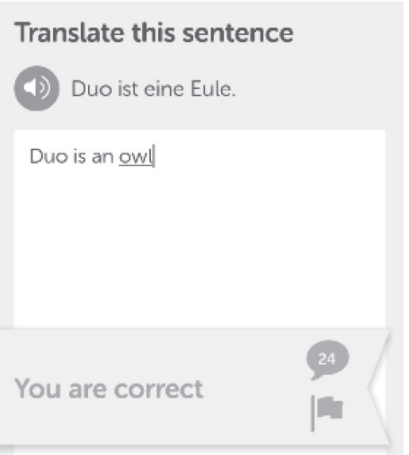

Slika 3. Dvojezični način semantizacije prevođenjem (samostalno prevođenje)

Nadalje, u aplikaciji se javljaju i dvojezični načini semantizacije internacionalizmima. Internacionalizmi koji se spominju $u$ Duolingu i olakšavaju razumijevanje vokabulara su npr. Europa, Kontinent, Pinguin, Musik, Post, Gitarre, Religion, Republik, Philosophie, Fotographie, Physik, Hobby itd.

Za razliku od aplikacije Duolingo, u udžbenicima za njemački jezik nudi se više načina semantizacije vokabulara, tj. različiti verbalni i neverbalni načini semantizacije. Kod neverbalnih načina semantizacije vokabular se objašnjava pomoću slika, brojeva ili piktograma, npr. slikom se pokušava objasniti značenje određenog frazema. Kod verbalnih načina semantizacije zastupljeni su i jednojezični i dvojezični načini objašnjavanja značenja. Od jednojezičnih načina semantizacije javljaju se objašnjenja koja se koriste 
paradigmatičnim odnosima, kao što su sinonimi (Kopfschmerzen haben = mein Kopf tut weh), antonimi (sich wohl fühlen $\neq$ krank sein), nizovi (eins, zwei, drei,...) $i$ drugi. U udžbenicima se ti načini semantizacije nalaze na kraju poglavlja u obliku sažetka cjeline.

U udžbenicima se također prikazuju objašnjenja značenja logičkokonceptualnim odnosima, kao što je hijerarhija (razvrstavanje vrsta voća i povrća). Od opisnih objašnjenja značenja javljaju se definicije, npr. Man ist ein unbestimmtes Pronomen (man je neodređena zamjenica). Također se značenje objašnjava kontekstom, kao u primjeru Die Kirche ist der Kölner Dom (Ova crkva je kölnska katedrala).

U aplikaciji su zastupljene četiri različite vrste vježbi. Najčešći je prijevod, što je ujedno i najčešći način semantizacije. Druga je najčešća vježba povezivanje parova, tj. učenik treba povezati riječ na njemačkom jeziku s njegovim engleskim prijevodom (slika 4). Riječi koje se trebaju povezati ponuđene su bez konteksta.

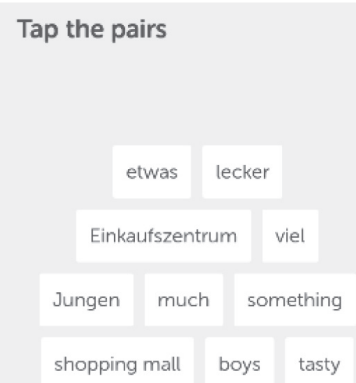

Slika 4. Vježba povezivanja parova

Treća najčešća vježba je slušanje i pisanje riječi ili rečenice, tj. uvježbavaju se vještine slušanja i pisanja (slika 5).

Type what you hear

())

Slika 5. Vježba slušanja i pisanja riječi 
U aplikaciji je učestala i vježba višestrukog izbora u kojoj učenici trebaju odabrati točnu riječ (slika 6) ili rečenicu (slika 7).

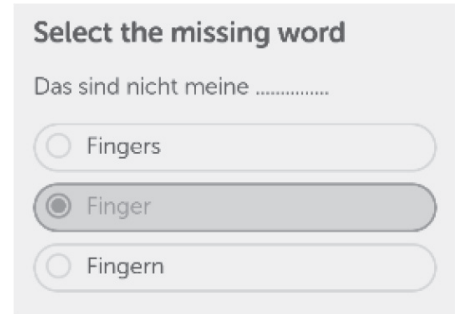

Slika 6. Vježba višestrukog izbora (odabir riječi)

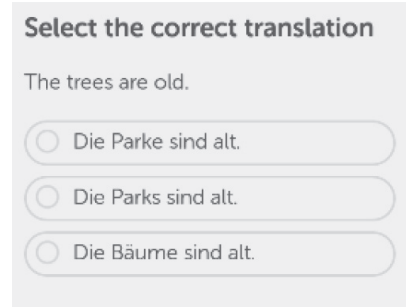

Slika 7. Vježba višestrukog izbora (odabir rečenice)

\subsection{Nedostaci aplikacije Duolingo}

U aplikaciji Duolingo pronađeni su određeni nedostaci koje bi proizvođači aplikacije trebali uzeti u obzir i eventualno ih unaprijediti. Pri korištenju aplikacijom za učenje stranih jezika polaznici trebaju biti svjesni sljedećih nedostataka:

(1) U aplikaciji se nalaze rečenice koje u svakodnevnim komunikacijskim situacijama nisu korisne, npr. Studenten sind auch Menschen (Studenti su također ljudi).

(2) Neke se rečenice ponavljaju više puta, čak šest puta $u$ nizu, npr. rečenica Duo, bist du eine Eule? (Duo, jesi li ti sova?). Rečenice se ponavljaju u svrhu uvježbavanja, ali bi razmak između ponavljanja trebao biti veći, tj. ista se rečenica ne bi trebala ponavljati više puta u istoj vježbi.

(3) Različite se varijante prijevoda ne prihvaćaju, nego se označavaju kao pogrešne (slika 8).

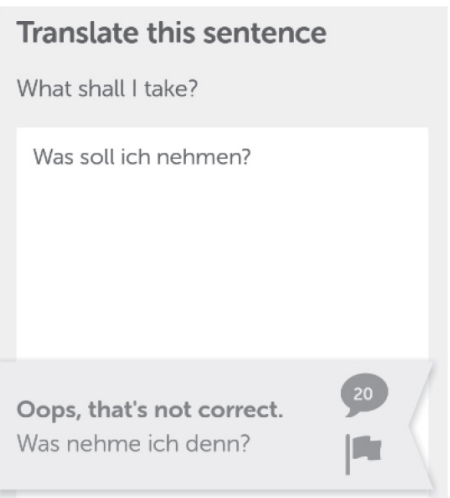

Slika 8. Varijante prijevoda koje su označene s 'netočno'

(4) Kod primjera gdje imenica ima isti oblik u jednini i množini, $u$ vježbama nije označeno zahtijeva li se određeni član u jednini ili množini (slika 9). 


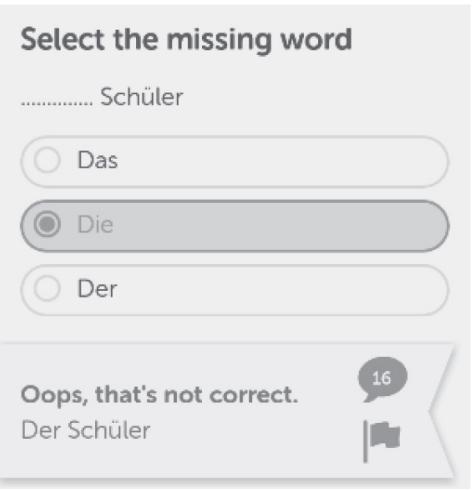

Slika 9. Nejasno formulirana uputa

(5) Novi vokabular obično se nalazi izvan konteksta, što otežava njegovu semantizaciju (slika 10).

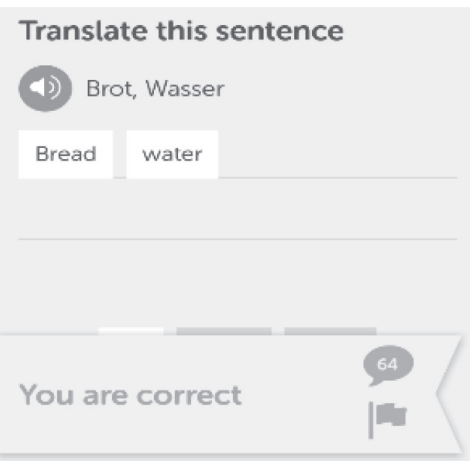

Slika 10. Riječi ponuđene izvan konteksta

(6) Aplikacija ne razlikuje riječi pisane velikim i malim početnim slovom (slika 11).

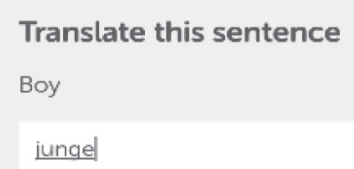

Slika 11. Nerazlikovanje velikog i malog početnog slova riječi 
(7) U aplikaciji postoji nekoliko razina (1-5), ali se isti vokabular javlja na razini 1 i na razini 5. Vokabular se ne proširuje na višim razinama. Jedina je razlika u količini vježbi.

(8) Odabir tema $u$ aplikaciji je nejasan. Učenicima se nude teme poput stvari i apstraktni objekti, ali nije jasno što se pod njima podrazumijeva jer su teme previše opsežne. Teme bi trebale biti jasnije i konkretnije.

\section{ZAKLJUČAK}

U ovom se radu prikazuju rezultati analize mogućnosti implementacije aplikacije Duolingo kao dodatnog nastavnog materijala za učenje njemačkog jezika. U aplikaciji Duolingo analizirani su odabir tema, načini semantizacije i uvježbavanja vokabulara, te su uspoređeni s onim iz udžbenika za njemački jezik.

Rezultati analize pokazali su da postoje određene zajedničke teme $\mathrm{u}$ Duolingu iudžbenicima koje se odnose na svakodnevnicu, npr. hrana, životinje, odjeća, obitelj, vrijeme itd. Postoje teme koje se javljaju samo u udžbenicima za njemački jezik. To su teme koje su prilagođene dobi i interesima adolescenata, npr. škola, mediji, oglašavanje, simpatije, slobodno vrijeme. U aplikaciji Duolingo nalaze se neutralne teme koje su prilagođene i adolescentima i odraslima, npr. politika, bankarstvo, umjetnost, emocije, medicina itd. što znači da ih je moguće implementirati u nastavu njemačkog kao stranog jezika. Svaki nastavnik, s obzirom na obrađivanu tematsku cjelinu, može koristiti vježbe iz aplikacije Duolingo kao dodatni nastavni materijal.

Izvorni govornici hrvatskog jezika ne mogu posegnuti za J1, nego za nekim drugim stranim jezikom (npr. engleski kao J2) kako bi se njime služili u učenju njemačkoga kao J3. Time se otvaraju mogućnosti povezivanja stranih jezika koje učenici uče u smislu didaktike višejezičnosti, odnosno didaktike trećih jezika (J3). Što se tiče načina semantizacije vokabulara u aplikaciji, analiza je pokazala da je najčešći verbalni dvojezični način semantizacije prevođenjem riječi ili rečenice. Verbalni se jednojezični način semantizacije u aplikaciji ne pojavljuje. Neverbalni način semantizacije pomoću slika je prisutan, ali je prilično rijedak. U aplikaciji postoje četiri različite vrste vježbi. Najčešći je prijevod, što je ujedno i najčešći način semantizacije. Osim toga, prikazuju se vježbe slušanja, višestrukog izbora i povezivanje parova. $\mathrm{S}$ obzirom na najčešće zastupljene vrste vježbi u aplikaciji Duolingo, ona se može koristiti za dodatno uvježbavanje prijevoda s J2 na J3.

Aplikacija Duolingo, s obzirom na odabir tema i semantizaciju vokabulara, može se primijeniti na razinama A1 i A2 za samostalno učenje njemačkog jezika u Hrvatskoj jer postoje preklapanja s izborom tema $\mathrm{u}$ hrvatskim udžbenicima za njemački jezik. Za razinu B1 aplikacija nije prikladna, jer ne postoji širenje vokabulara koje odgovara razini B1. 
Korištenje aplikacije Duolingo za učenje njemačkog kao stranog jezika omogućava povezivanje nastave jezika s učenikovim svakodnevnim korištenjem medija. Učenik na zabavan način i izvan učionice može vježbati vokabular i jezične strukture.

\section{LITERATURA}

Bohn, R. (1999) Probleme der Wortaschatzarbeit. Fernstudieneinheit 22. Berlin: Langenscheidt.

Müller, B.-D. (1994) Wortschatzarbeit und Bedeutungsvermittlung. Fernstudieneinheit 8. Berlin: Langenscheidt.

Brinitzer, M., Hantschel, H.-J., Kroemer, S., Möller-Frorath, M. i Ros, L. (2016) DaF Unterrichten. Basiswissen Didaktik Deutsch als Fremd- und Zweitsprache. Stuttgart: Klett Verlag.

Brinkmann, D. (2000) Moderne Lernformen und Lerntechniken in der Erwachsenenbildung. Formen selbstgesteuerten Lernens. Bielefeld: Institut für Freizeitwissenschaft und Kulturarbeit e.V. (IFKA).

Duolingo - https://www.duolingo.com (preuzeto 9. 10. 2018.)

Feick, D. (2015) Mehr als nur Apps. Mobiles Lernen im DaF-Unterricht. Fremdsprache Deutsch 53 Unterrichten mit digitalen Medien. 14-18.

Grewe, I. (2011) Neue Medien - Gefahren und Chancen. Norderstedt: GRIN Verlag.

Horvatić Čajko, I. i Lasić, I. (2006) zweite.sprache@DEUTSCH.de 1. Udžbenik njemačkog jezika za 1. razred gimnazije, I. godina učenja, 2. strani jezik. Zagreb: Školska knjiga.

Horvatić Čajko, I. i Lasić, I. (2013) zweite.sprache@DEUTSCH.de 2. Udžbenik njemačkog kao drugog jezika za 2. razred gimnazija i četverogodišnjih strukovnih škola. Zagreb: Školska knjiga.

Horvatić Čajko, I. i Lasić, I. (2008) zweite.sprache@DEUTSCH.de 3. Udžbenik njemačkog kao drugog jezika za 3. razred gimnazija i strukovnih škola, 3. godina učenja. Zagreb: Školska knjiga.

Horvatić-Čajko, I. i Lasić, I. (2009) zweite.sprache@DEUTSCH.de 4. Udžbenik njemačkog kao drugog jezika za 4. razred gimnazija i strukovnih škola, 4. godina učenja. Zagreb: Školska knjiga.

Kleimann, B., Özkilic, M. i Göcks, M. (2008) Studieren im Web 2.0. Studienbezogene Web- und E-Learning-Dienste. HISBUS Kurzinformation 21. Hannover. https://hisbus.his.de/hisbus/docs/ hisbus21.pdf (preuzeto: 9. 10. 2018.)

Moser, H. i Holzwarth, P. (2011) Mit Medien arbeiten. Lernen - Präsentieren - Kommunizieren. Konstanz: UVK Verlagsgesellschaft.

Neuner, G., Krüger, M. i Grewer, U. (1981) Übungstypologie zum kommunikativen Deutschunterricht. München: Langenscheidt.

Schmale, W., Gasteiner, M., Krameritsch, J. i Romberg, M. (2007) E-Learning Geschichte. Wien: Böhlau Verlag.

Steinig, W. i Huneke, H.-W. (2011) Sprachdidaktik Deutsch. Eine Einführung. Berlin: Erich Schmidt Verlag.

Süss, D. (2004) Mediensozialisation von Heranwachsenden. Dimensionen - Konstanten - Wandel. Wiesbaden: VS Verlag.

Vesselinov, R. i Grego, J. (2012) Duolingo Effectiveness Study. http://static.duolingo.com/s3/DuolingoReport_Final.pdf (preuzeto 18. 07.2018)

Vijeće Europe (2005) Zajednički europski referentni okvir za jezike: učenje, poučavanje, vrednovanje. Školska knjiga: Zagreb. 


\section{IMPLEMENTATION OF THE DUOLINGO APPLICATION IN THE TEACHING OF GERMAN AS A FOREIGN LANGUAGE}

Duolingo is an application that is used very often for foreign language learning all around the world. The aim of the analysis presented in this article is to examine the possibility of implementing the Duolingo app in the teaching of German as a Foreign Language. The selection of topics and the explanation of the vocabulary in the application will be compared to those in Croatian textbooks for teaching German as a foreign language. As Croatian textbooks for teaching German as a foreign language are compiled according to the guidelines of the Common European Framework of Reference for Languages (CEFR), this research will show if the Duolingo application complies with the guidelines that can be derived from CEFR for the selection of topics. Furthermore, the following questions will be answered: Are there similarities or differences in a) the selection of topics, b) explanation of vocabulary and c) vocabulary exercises in the application and in the textbooks? The purpose of the paper is to determine the applicability of the Duolingo application in learning German as a Foreign Language.

Keywords: media in foreign language teaching, Duolingo application, teaching German as a foreign language. 